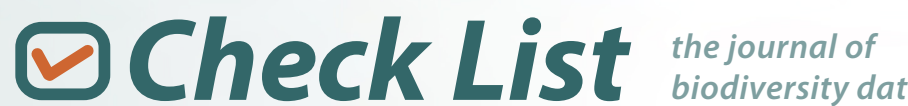

$\oslash$

\section{Occurrence of Astyanax dissensus Lucena \& Thofehrn, 2013 (Teleostei: Characidae) in Argentina}

\author{
Guillermo Enrique Terán $^{1 *}$, Felipe Alonso ${ }^{2}$, Ignacio García ${ }^{3}$, Pablo Calviño ${ }^{4}$ and Juan Marcos Mirande ${ }^{1}$ \\ 1 UEL-CONICET-Fundación Miguel Lillo, Miguel Lillo 251, 4000 Tucumán, Argentina \\ 2 División de Ictiología, Museo Argentino de Ciencias Naturales, “Bernardino Rivadavia” CONICET. Av. Ángel Gallardo 470, Buenos Aires, \\ Argentina \\ 3 Instituto de Limnología "Dr. Raúl A. Ringuelet", CONICET, Boulevard 120 y 62, La Plata, Argentina \\ 4 Grupo de Estudios del Killi Club Argentino (KCA). Aristóbulo del Valle 5125, Villa Ballester, Buenos Aires, Argentina \\ * Corresponding author. E-mail: guilloteran@gmail.com
}

Abstract: The occurrence of Astyanax dissensus in the Uruguay River, at Yapeyú, Corrientes, Argentina is reported for the first time in the country.

Key words: biogeography; Characiformes; species distribution; Uruguay River

The genus Astyanax Baird \& Girard (Characiformes: Characidae) includes more than 140 valid species (Eschmeyer and Fricke 2015) and is the most diverse genus of Characidae.

Recently, Mirande and Koerber (2015) listed 29 species of Astyanax in Argentina. There are 16 species of this genus in the Uruguay River basin and laguna dos Patos system drainages (see Table 2 of Lucena et al. 2013), of which seven are known to occur in Argentina.

The Uruguay River basin has an area of approximately $350,300 \mathrm{~km}^{2}$; with a length of about 2,200 km from its headwaters in the foothills of Serra do Mar, Brazil to its mouth, where it converges with the Paraná River to create the Río de La Plata estuary (Sverlij et al. 1998). According to Ringuelet (1975), there is a great concordance between the fish species of the Paraná and Uruguay basins. López et al. (2008) defined both basins as belonging to the Argentinian ichthyological "province of The Great Rivers", which supports at least 394 fish species, by far the richest in Argentina in terms of fish diversity.

Astyanax dissensus Lucena \& Thofehrn, 2013 was described from the laguna dos Patos system, Uruguay River drainage, and from a coastal lagoon of the Tramandaí River system (Lucena et al. 2013). Later, Serra et al. (2014) reported this species in the main channel of the Río Negro and in Tupambaé stream, Uruguay.
This study reports the first occurrence of Astyanax dissensus in the Uruguay River basin in Argentina (Figure 1).

A close examination of Astyanax museum specimens (Figure 2), housed at the ichthyological collections of Fundación Miguel Lillo (CI-FML) and Museo Argentino de Ciencias Naturales (MACN-ict), from the Uruguay River at Yapeyú, Corrientes, Argentina, allowed us to identify all of the specimens as A. dissensus (Figure 2).

Counts and measurements were taken as described by Fink and Weitzman (1974). Measurements were taken

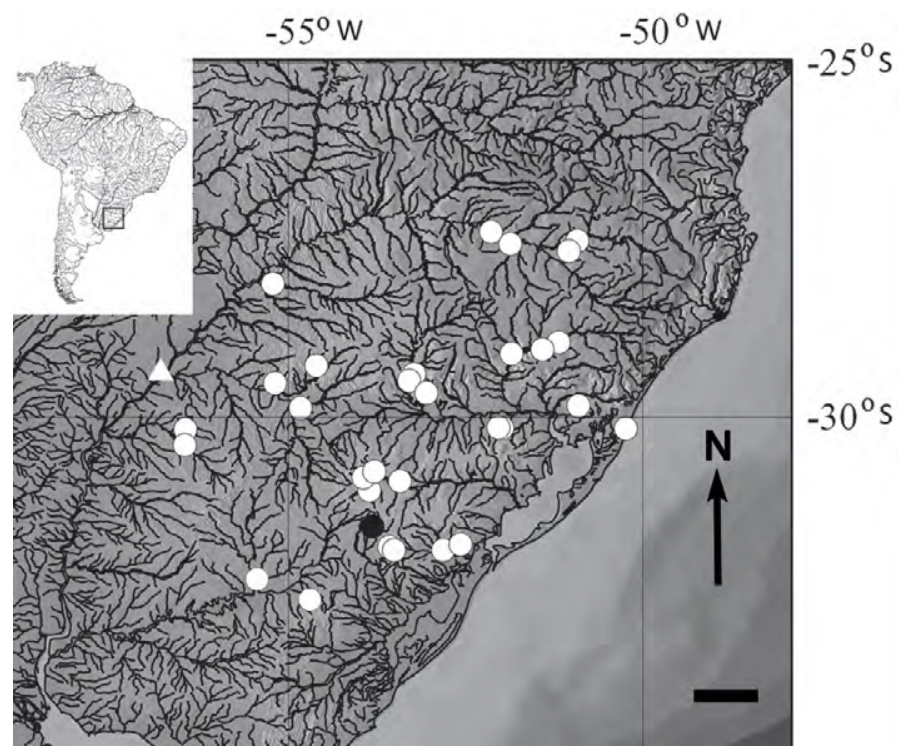

Figure 1. Previous and new records for Astyanax dissensus. Map modified from Lucena et al. (2013). Circles indicate previous records in Brazil (Lucena et al. 2013) and Uruguay (Serra et al. 2014). Black circle indicates type locality. The white triangle indicates the new record for this species in Uruguay River at Yapeyú, Corrientes, Argentina (29²8'05.03" S, 05648'32.72" Wi $45 \mathrm{~m}$ above sea level). Scale bar $=100 \mathrm{~km}$. 


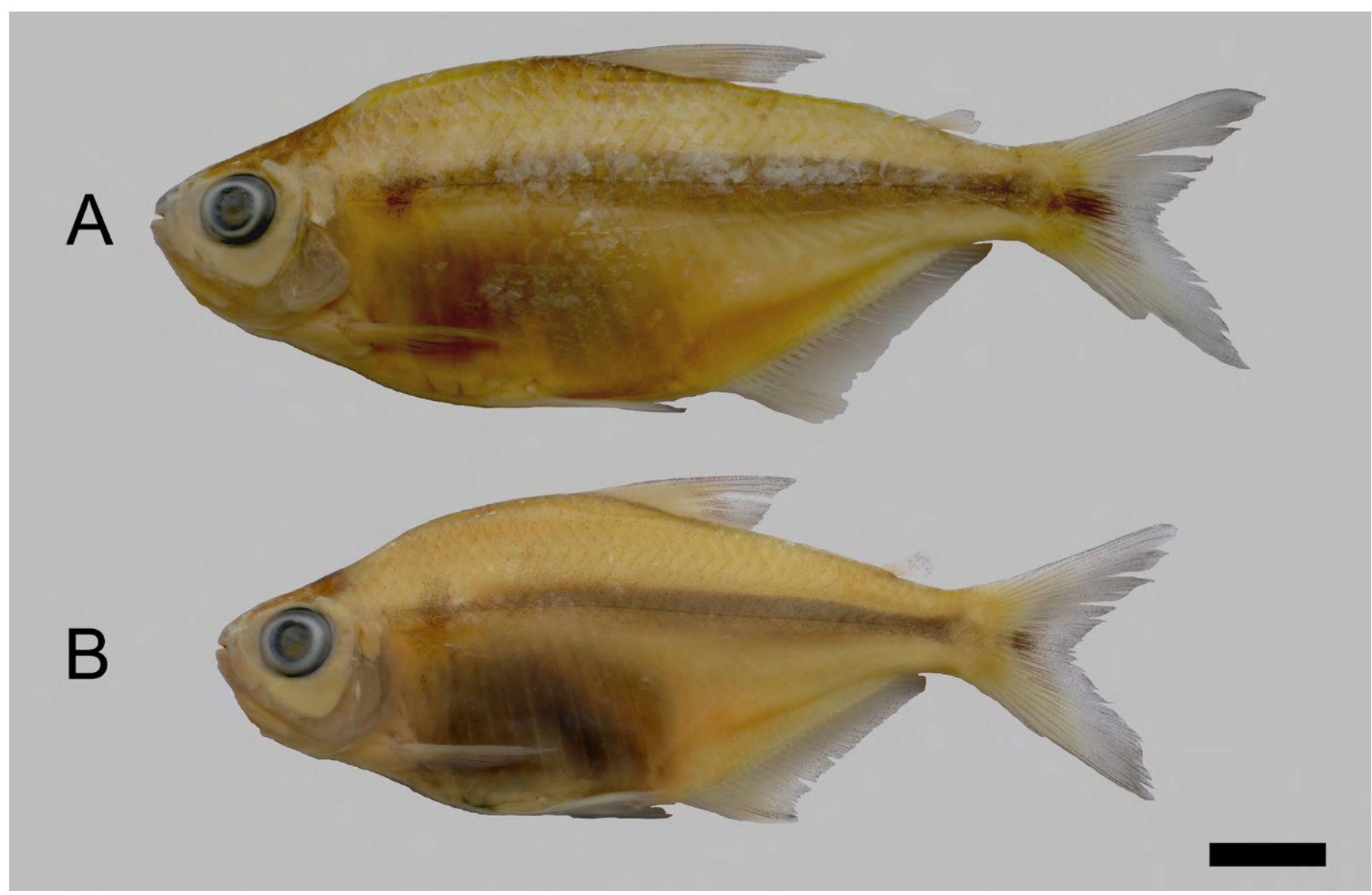

Figure 2. Astyanax dissensus, Cl-FML 6183. A: Male, 81.3 mm SL. B: Female, $69.2 \mathrm{~mm} \mathrm{SL}$, from Uruguay River at Yapeyú, Corrientes, Argentina. Scale bar = $10 \mathrm{~mm}$.

point to point with a caliper and are expressed as percentage of standard length (SL) or percentage of head length (HL). Morphometric measurements are provided in Table 1.

Table 1. Morphometrics of 24 specimens of Astyanax dissensus, Cl-FML 6183 and MACN-ict 10911.

\begin{tabular}{llll}
\hline & Mean & Range & SD \\
\hline Standard length (mm) & 70.9 & $54.3-88.6$ & - \\
\hline Percent of standard length & & & \\
Predorsal distance & 50.9 & $48.6-52.4$ & 0.9 \\
Preanal distance & 65.2 & $62.8-67.3$ & 1.1 \\
Preventral distance & 48.40 & $46.7-50.1$ & 0.9 \\
Body depth & 41.0 & $39.0-43.7$ & 1.2 \\
Dorsal-fin base & 14.5 & $13.1-16.4$ & 0.9 \\
Anal-fin base & 32.2 & $30.0-34.4$ & 1.1 \\
Pectoral-fin length & 21.5 & $19.5-22.7$ & 0.7 \\
Pelvic-fin length & 17.3 & $15.5-20.3$ & 1.0 \\
Pectoral to pelvic-fin distance & 21.4 & $19.6-22.8$ & 0.7 \\
Pelvic to anal-fin distance & 19.4 & $17.1-21.0$ & 0.8 \\
Head length & 25.7 & $23.8-27.3$ & 0.8 \\
Peduncle depth & 11.3 & $10.7-12.2$ & 0.3 \\
Peduncle length & 10.1 & $9.0-11.3$ & 0.7 \\
\hline Percent of head length & & & \\
Eye diameter & 36.9 & $34.4-40.7$ & 1.4 \\
Interorbital width & 30.9 & $28.5-33.5$ & 1.3 \\
Postorbital distance & 45.3 & $42.0-49.0$ & 2.0 \\
Snout length & 23.9 & $21.8-26.0$ & 0.9 \\
Maxillary length & 25.5 & $23.2-27.1$ & 0.9 \\
Upperjaw length & 37.5 & $35.2-40.0$ & 1.0 \\
\hline & & & \\
\hline
\end{tabular}

Examined material. CI FML 6183, 20 specimens (4 cleared and stained), 54.3-88.6 mm SL, Uruguay River, Río de la Plata system, Yapeyú, Corrientes, Argentina, $29^{\circ} 28^{\prime} 5.03^{\prime \prime} \mathrm{S}, 056^{\circ} 48^{\prime} 32.72^{\prime \prime} \mathrm{W}, 45 \mathrm{~m}$ above sea level, June 2006. J.E. Sola; MACN-ict 10911, 4 specimens, 63.1-78.8 $\mathrm{mm} \mathrm{SL}$, same data as previous.

Specimens were identified using the artificial key provided by Lucena et al. (2013) and corroborated by comparison with the species description.

Analyzed specimens present the combination of characters proposed in the description of the species: one developed heptacuspid tooth on the maxilla, 22-28 branched anal-fin rays, 35-39 perforated scales along the lateral line, two humeral spots, conspicuous lateral band continuous on middle caudal rays, $6-7$ scale rows between the dorsal-fin origin and lateral line, and head length 22.7-27.3\% of SL (Lucena et al. 2013).

Also, males bear tiny hooks on anal-fin and pelvic-fin rays as described by Lucena et al. (2013).

This is the first record of Astyanax dissensus in Argentina. The expansion of the known geographical distribution of $A$. dissensus in the area of the Uruguay River basin and its addition to the fauna of freshwater fishes of Argentina, are part of the requirement of the Convention on Biological Diversity (CBD) which proposes that each country should have accurate and updated lists of fauna and flora (Reis et al. 2003). From this perspective, 
the record herein is also a new source of reference for biodiversity projects and biological conservation of basins, contributing to the conservation of the highly diverse South American freshwater fish fauna.

\section{ACKNOWLEDGEMENTS}

We would like to thank to CONICET, Fundación Miguel Lillo, and FONCyT (PICT-2011-0992to JMM) for financial support.

\section{LITERATURE CITED}

Eschmeyer, W.N. and R. Fricke (eds.). 2015. Catalog of fishes: genera, species, references. Accessed at http://research.calacademy.org/ research/ichthyology/catalog/fishcatmain.asp, January 2015.

Fink, W.L. and S.H. Weitzman. 1974. The so-called cheirodontinfishes of Central America with descriptions of two newspecies (Pisces: Characidae). Smithsonian Contributions to Zoology 172: 1-46. doi: $10.5479 /$ si.00810282.172

Mirande J.M. and S. Koerber. 2015. Checklist of the freshwater fishes of Argentina (CLOFFAR). Ichthyological Contributions of Peces Criollos 36: 1-68. http://media.hotelwebservice.com/media/ pecescriollos/docs/icp_36_-_mirande_koerber_2015_cloffar.pdf

López, H.L., R.C. Menni, M. Donato and A.M. Miquelarena. 2008. Biogeographical revision of Argentina (Andean and Neotropical Regions): na analysis using fresh water fishes. Journal Biogeo- graphy 35(9): 1564-1579. doi: 10.1111/j.1365-2699.2008.01904.x

Lucena, C.A.S., J.B. Castro, and V.A. Bertaco. 2013. Three new species of Astyanax from river drainages of southern Brazil (Characiformes: Characidae). Neotropical Ichthyology. 11: 537-552. doi: 10.1590/S1679-62252013000300007

Reis, R.E., S.O. Kullander, and C.J. Ferraris. 2003. Check list of the freshwater fishes of South and Central America. Porto Alegre: EDIPUCRS. $729 \mathrm{pp}$.

Ringuelet, R.A. 1975. Zoogeografía y ecología de los peces de aguas continentales de Argentina y consideraciones sobre las áreas ictiológicos de América del Sur. Ecosur 2(3): 1-122.

Serra, W.S., J. Bessonart, F. Teixeira de Mello, A. Duarte, L. Malabarba and M. Loureiro. 2014. Peces del Rio Negro. Montevideo: MGAPDINARA. 208 pp.

Sverlij, S.B., R.L.D., Schenke, H.L. López , A. Escpinach Ros. 1998. Peces de Río Uruguay. C.A.R.U, Publicaciones de la Comisión Administrativa del Río Uruguay. 90 pp.

Author contributions: GET and JMM identified material from CI-FML; FA, IG, PC identified material from MACN-ict. GET made the measurements of the examined material; FA made the map; JMM photographed the specimens. GET, FA and JMM wrote the MS. All authors corrected the final version of the manuscript.

Received: 7 October 2015

Accepted: 3 January 2016

Academic editor: Tiago Carvalho 